\title{
The Views of Contemporer Mut'ah Marriage Among Yogyakarta Shi'ite Leaders
}

\author{
Muhammad Muhajir*, Muhammad Fadli Kamil* \\ Mahasiswa Magister Ilmu Syariah, Fakultas Syariah dan Hukum Universitas Islam Negeri Sunan Kalijaga Jl. \\ Marsda Adisucipta, Yogyakarta, Indonesia 55281. Email: hajirsyarof@gmail.com* dan Email: \\ fadhlikamil12@gmail.com**
}

\begin{abstract}
This paper explicates the views of Shia leaders in Rausyan Fikr Foundation Yogyakarta on mut'ah marriage. There have been various views related to mut'ah marriage law by Rausyan Fikr leaders. On one side, Shi'ite school of thought is hitherto the only proponent to the mut'ah marriage. This research is descriptive-analytic study using normative approaches by examining the views of Yogyakarta Shi'ite leaders in justifying the marriage using Islamic law including the Qur'an, Hadith, and Fiqh principles or ushuliyyah. The study finds that there are three opinions among Shi'ite leaders in Yogyakarta; 1) Some leaders strictly prohibit due to the differences in places and conditions between Indonesia and Iran, 2)Some of them allow it with the condition that marriage must be conducted with fellow Shi'ite, 3) Some believe it is allowed according the Ja'fari school of thought without considering conditions and places. Despite the differences of views among Yogyakarta Shia leaders, these differences can be compromised by seeing that mut'ah marriage is unacceptable under normal circumstances, but in an emergency situation, it can certainly be justifiable by considering its maslahat (benefit) or mudarat (danger).
\end{abstract}

Keywords: mut'ah marriage, Islamic law, Yogyakarta Shia leaders

\section{Pandangan Tokoh Syiah Yogyakarta tentang Nikah Mut'ah dan Implementasinya di Era Kontemporer}

\begin{abstract}
Abstrak
Tulisan ini membahas tentang nikah mut'ah dan penerapannya dalam pandangan tokoh Syiah di Yayasan Rausyan Fikr Yogyakarta. Diketahui bahwa terjadi perbedaan pandangan terkait hukum nikah mut'ah oleh para tokoh Rausyan Fikr. Di sisi lain, kita ketahui bahwa mazhab Syiah adalah satu-satunya mazhab yang konsisten dengan argumentasi bahwa nikah mut'ah tetap berlaku hingga akhir zaman. Penelitian ini merupakan penelitian lapangan (field research) bersifat deskriptif-analitik dengan menggunakan pendekatan normatif dengan mengkaji pandangan para tokoh Syiah Yogyakarta menggunakan hukum Islam secara mayoritas meliputi al-Qur'an, Hadis dan kaidah-kaidah fiqhiyyah ataupun ushuliyyah. Hasil penelitian ini adalah terdapat tiga pendapat dari tokoh Syiah di Yogyakarta; yaitu 1) melarang secara mutlak dengan alasan perbedaan tempat dan kondisi antara Indonesia dan Iran, 2) membolehkan dengan syarat pernikahan harus dilakukan dengan sesama penganut Syiah, 3) membolehkan secara mutlak berlandasan pada fikih mazhab Syiah Ja'fari tanpa mempertimbangkan perbedaan kondisi dan tempat. Terlepas perbedaan pandangan di kalangan tokoh Syiah Yogyakarta, perbedaan tersebut dapat dikompromikan dengan melihat bahwa nikah mut'ah tidak dapat diterima dalam keadaan normal, namun dalam keadaan darurat tentu dapat dipertimbangkan dan dilihat mana lebih besar maslahat dan mudaratnya.
\end{abstract}

Kata Kunci: nikah mut'ah, hukum Islam, tokoh Syiah Yogyakarta

* Naskah diterima September 2021, direvisi Oktober 2021, dan disetujui untuk diterbitkan November 2021

Dialog, 44(2), 2021, 216-229

https://jurnaldialog.kemenag.go.id,p-ISSN: 0126-396X,e-ISSN: 2715-6230

This is open access article under CC BY-NC-SA-License

(https://creativecommons.org/license/by-nc-sa/4.0/)

Dialog Vol. 44, No.2, Desember 2021

216 


\section{A. Pendahuluan}

Sebagai manusia sosial, seseorang membutuhkan orang lain dalam hidupnya. Pernikahan merupakan salah satu jalan untuk memenuhi kebutuhan tersebut. Pernikahan adalah cara yang dipilih oleh Allah bagi manusia untuk mempertahankan garis keturunan dan membangun peradaban dunia (Al-Musayyar, 2008). Selain itu, pernikahan sebagai pembeda antara manusia dan hewan dalam melampiaskan birahi seksualnya. Oleh sebab itu, pernikahan adalah cara paling baik yang Allah berikan untuk melindungi harga diri dan martabat manusia ('Abdirrazzaq, 2010).

Secara etimologis, perkawinan bermakna berkumpul, menjalin dan hubungan seksual (Munawwir, 1997). Imam Syafii menjelaskan nikah secara terminologi sebagai suatu akad yang membuat hubungan antara pria dan wanita menjadi halal (Arifin, 2016). Pasal 1 Undang-Undang Nomor 1 Tahun 1974 tentang Perkawinan juga menjelaskan definisi perkawinan sebagai ikatan lahir batin antara seorang pria dan wanita untuk menjadi suami istri dengan maksud menciptakan keluarga yang tentram dan abadi berdasarkan ketuhanan yang Maha Esa. Dari beberapa pengertian tersebut dapat disimpulkan bahwa perkawinan adalah suatu akad yang mengesahkan hubungan antara seorang laki-laki dan seorang perempuan, tidak hanya itu, suatu perkawinan merupakan perjanjian lahir batin yang mempunyai maksud untuk mewujudkan keluarga yang tentram dan langgeng.

Islam memandang perkawinan tidak hanya sebagai bentuk legitimasi hubungan antara suami dan istri, tetapi perkawinan sebagai pemenuhan separuh agama dan sunnah Nabi Muhammad saw. yang mempunyai maksud agar berupaya membentuk keluarga yang harmonis (Amir, 2014). Sebagaimana yang dijelaskan dalam Q.S Ar-Rum (30) ayat 21.

Ayat di atas menjelaskan bahwa Allah menciptakan pasangan untuk orang-orang sejenis, agar tercipta rasa damai dan tentram antara pasangan yang pada akhirnya keluarga yang harmonis akan tercipta.

Dalam kajian fikih munakahat, terdapat pembahasan yang cukup familiar bagi para kritikus, yaitu nikah mut'ah atau nikah muaqqat atau lebih dikenal dengan nikah kontrak. Nikah mut'ah merupakan perkawinan yang dikerjakan dengan batas waktu tertentu. Menurut Wahbah azZuhaili, nikah mut'ah adalah akad nikah dengan jangka waktu tertentu, karena seorang pria dapat menikahi seorang perempuan dalam sehari, seminggu, sebulan, dan seterusnya (Az-Zuhaili, 2011).

Dalam nikah mut'ah tidak diperbolehkan menceraikan istri sebelum habis kadaluarsa (Emilia Renita AZ, 2013), dan siapa saja yang melangsungkan nikah mut'ah dapat juga mengubahnya dengan nikah permanen ( $\left.d a^{\prime} i m\right)$. Dengan kata lain nikah mut'ah adalah nikah sementara yang dapat dilanggengkan, dan nikah da'im adalah nikah untuk selamanya tetapi sewaktu-waktu bisa putus.

Para fuqahâ' baik itu dari Sunni maupun Syiah sepakat bahwa Nabi Muhammad saw. pernah menghalalkan nikah mut'ah, namun mereka berbeda pandangan tentang larangan tersebut. Mazhab Syiah mengikuti pendapat konsensus bahwa pernikahan mut'ah disyariatkan berdasarkan firman Allah dalam Q.S An-Nisa ayat 24.

Menurut Al-Fakhr Al-Razi yang dikutip oleh Emilia Renita, ayat di atas secara khusus menggambarkan pernikahan mut'ah, karena ayat tersebut menunjukkan bahwa pemberian mahar wajib hanya karena istimta'. Istimta' memiliki arti menikmati dan menggunakan, sedangkan dalam nikah biasa atau da'im, mahar diwajibkan bukan karena istimta' melainkan karena akad nikah itu sendiri. Jika ayat tersebut dikenakan pada nikah biasa, maka akan terjadi pengulangan penetapan hukum nikah dalam surat yang sama. Tetapi jika hal ini dikenakan pada nikah mut'ah, maka Allah membuat hukum yang baru, dan ini lebih tepat (Emilia Renita AZ, 2013).

Berbicara tentang nikah mut'ah, kita tidak bisa menghindari diskusi kaum Syiah, kelompok yang mendukung keberadaan nikah mut'ah itu sendiri. Kelompok ini 
muncul pada masa pemerintahan Ali bin Abi Thalib. Syiah adalah istilah bagi golongan yang menyakini dan mendukung Ali bin Abi Thalib untuk menggantikan kepemimpinan Rasulullah setelah wafatnya beliau (Atjeh, 1977).

Syiah masuk ke Indonesia melalui Aceh oleh para misionaris Persia yang tinggal di Gujarat. Bahkan Raja pertama Samudera Pasai Marah Silu yang bergelar Malikul Saleh menganut ajaran syiah. Namun ketika kekuasaan dipegang oleh ulama Sunni (Ahlus Sunnah wal Jama'ah) pada zaman Sultan Iskandar Tsani, sejak saat itu Syiah bersembunyi dan tidak menampakkan diri lagi sampai terjadinya revolusi Islam di Iran. Setelah Ayatullah Khomeini meluncurkan Revolusi Islam Iran pada tahun 1979, Syiah mulai mendapat simpati dari berbagai kalangan aktivis Islam, dan banyak masyarakat Indonesia yang mulai mempelajari fikih Syiah dari para habibhabib yang pernah belajar di Khum. Kemudian beberapa tahun pasca Revolusi Islam Iran, Syiah menyebar ke beberapa kota di Indonesia, termasuk Yogyakarta. Dari penyebaran itu dibentuklah sebuah organisasi bersama bernama Ikatan Jama'ah Ahlul Bait Indonesia (IJABI) (Hasim, 2012).

Kehadiran Syiah di Yogyakarta sebenarnya sudah ada sejak lama. Namun, sulit untuk mengetahui awal dari keberadaan Syiah ini karena para penganutnya tersebar dan tidak tinggal dalam satu wilayah tertentu (Agus, 2008). Setelah terjadinya revolusi Iran yang dipimpin oleh Ayatullah Khomeini, Syiah mulai dikenal dan banyak mahasiswa yang tertarik untuk mempelajari dan mendiskusikan pemikiran para tokoh Syiah, terutama di bidang filsafat dan tasawuf seperti Ali Syariati dan Murtadha Muthahari. Dari ketertarikan tersebut, maka dibentuklah kelompok diskusi di kalangan mahasiswa yang memiliki pemikiran yang sama, dan pada pertengahan tahun 1995, sebuah yayasan yang bernama Rausyan Fikr didirikan untuk meresmikan diskusi tersebut ("Profil Rausyan Fikr Institute," n.d.).

Rausyan Fikr adalah yayasan yang memiliki kepentingan keagamaan dalam perspektif Ahlul Bait atau yang lebih dikenal dengan Syiah. Dari hasil observasi dan dikuatkan dengan wawancara kepada tokoh yayasan, diketahui bahwa yayasan ini berfokus pada studi filsafat dan tasawuf atau mistisisme oleh para filosuf muslim Iran. Dari hasil pra-penelitian diketahui bahwa terjadi perbedaan pandangan terkait hukum nikah mut'ah oleh para tokoh Rausyan Fikr. Di sisi lain, kita ketahui bahwa mazhab Syiah adalah satu-satunya mazhab yang konsisten dengan argumentasi bahwa nikah mut'ah tetap berlaku hingga akhir zaman. Menurut mereka, politik hukum pemerintahan Umar bin Khattab yang telah melarang eksistensi nikah mut'ah, padahal tidak ada dalil yang menasakh ayat yang menerangkan kebolehan nikah mut'ah (alMusawi, 2002). Berangkat dari sini peneliti tertarik untuk melakukan penelitian terhadap pandangan beberapa tokoh Syiah Yogyakarta terkait nikah mut'ah dan penerapannya di Yogyakarta.

Penelitian tentang nikah mut'ah sudah banyak dilakukan. Tulisan-tulisan tersebut dapat dikelompokan menjadi dua. Kelompok pertama tentang perdebatan Mazhab Sunni dan Syiah terhadap status hukum nikah mut'ah. Tulisan-tulisan tersebut di antaranya adalah tulisan Subhan. Subhan mencoba melacak dan mengomparasikan argumentasi yang mendasari pandangan Sunni dan Syiah tentang nikah mut'ah. Adapun hasil kesimpulan dari artikel ini pandangan Sunni mengatakan nikah mut'ah hukumnya haram dengan menggunakan metode komparatif berdasarkan QS. An-Nisa [4]: 24, al-Mu'minun [23]: 5-7 dan at-Talaq [56]: 1. Sedangkan argumentasi Syiah bahwa anNisa ayat 24 adalah dalil naqli dibolehkannya nikah mut'ah, terkait larangan nikah mut'ah hanya sebuah ijtihad dari Umar bi Khattab yang merupakan dalil aqli yang memungkinkan untuk diinterpretasi (Subhan, 2018).

Kemudian artikel Zanariah Noor melacak asal mula perbedaan antara Sunni dan Syiah tentang hukum nikah mut'ah dengan menonjolkan sumber dan 
argumentasi dari kedua belah pihak serta menyoroti perbedaan dalam syarat 'aqd dan akibat yang timbul dari mut'ah (Noor, 2014). Idris, Lutfiah dan Ahmadi membahas tentang nalar fiqh Syi'ah al-Tabatabai dalam topik "nikah mut'ah" dalam karyanya tafsir al-Mizan fi Tafsir al-Qur'an. Al-hasil, dalam tafsirnya, al-Tabatabai memposisikan dirinya sebagai pembela mazhab fikih Syi'ah (Idris, Lutfiah, \& Ahmadi, 2020).

Selanjutnya tulisan Yuliana Jamaludin menganalisa Tafsir al-Jabiri, khususnya tentang nikah mut'ah, dengan menggunakan teori ilmu pengetahuan atau epistemologi, sehingga fokus tulisan ini adalah sumber, metode, dan validitas tafsirnya. Meskipun al-Jabiri memposisikan dirinya di antara Sunni dan Syiah, nikah mut'ah menurutnya boleh jika dalam kondisi yang mendesak. Namun argumentasi yang ditawarkan dalam tafsirnya masih terdapat polemik. Deskripsi konsep darurat masih dipertanyakan seperti apa (Jamaluddin, 2020).

Sedangkan tulisan kelompok kedua menerangkan hukum nikah mut'ah beserta dampaknya. Tulisan-tulisan tersebut adalah artikel Muhammad Ali yang membahas tentang dampak nikah mut'ah terhadap kelangsungan suatu pernikahan. Dalam kesimpulannya, keluarga yang dibangun atas akad yang tidak dibatasi dengan waktu (daim) sangat sulit mewujudkan keluarga sakinah, apalagi pernikahan yang dibatasi dengan waktu (mut'ah) (Ali, 2016).

Kemudian tulisan Nurul Maghfiroh, Heniyatun, dan Puji Sulastyaningsih menunjukkan bahwa akibat hukum dari perkawinan kontrak adalah suami istri tidak dapat saling mewarisi karena perkawinan mereka tidak sah. Dampak lain, dari segi kesehatan, kawin kontrak membahayakan perempuan karena berganti pasangan menyebabkan penyakit kelamin. Selain itu, suami tidak memiliki tanggung jawab untuk memberikan nafkah kepada istri. Akibat hukum bagi anak adalah hanya menjadi ahli waris dari ibu dan keluarga ibunya. Upaya untuk mencegah atau mengurangi nikah kontrak adalah dengan memberikan sosialisasi/edukasi tentang dampak negatifnya dan memberikan pemahaman agama yang menjadi hal penting untuk mencegah seseorang tidak melakukan nikah kontrak (Maghfiroh, Heniyatun, \& Sulistyaningsih, 2016).

Tulisan ini mengkaji pandangan Tokoh Syiah di Yayasan Rausan Fikr Yogyakarta. Dalam pandangan mereka masih terjadi perbedaan hukum nikah mut'ah dan aplikasinya di era kekinian. Dari perbedaan tersebut menarik untuk diteliti bagaimana argumentasi masing-masing tokoh dan kemudian pendapat-pendapat tersebut dapat ditarik benang merah dalam pelaksanaanya di Indonesia dan khususnya di Yogyakarta.

\section{B. Metode Penelitian}

Jenis penelitian ini adalah penelitian lapangan (field research), yaitu penelitian yang sumber datanya diperoleh dari observasi ataupun wawancara terhadap subjek penelitian (Ruane, 2013). Dalam penelitian ini dilakukan wawancara terhadap para tokoh Syiah di Yayasan Rausyan Fikr Yogyakarta. Penelitian ini bersifat deskriptif-analitik dengan menggunakan pendekatan normatif, yakni dengan mengkaji pandangan para tokoh Syiah Yogyakarta dengan menggunakan hukum Islam secara mayoritas meliputi alQur'an, Hadis dan kaidah-kaidah fiqhiyyah atupun ushuliyyah. Dengan analisa demikian, akan ditemukan mana yang lebih maslahat antara melakukan nikah mut'ah atau tidak.

\section{Hasil dan Pembahasan \\ Nikah Mut'ah, Syarat, dan Rukunnya}

Kata mut'ah sendiri memiliki arti bersenang-senang (Murata, 2001), jika disebut nikah mut'ah maka yang dimaksud adalah pernikahan yang dilakukan untuk bersenang-senang. Menurut Imam Syafi'i nikah mut'ah adalah pernikahan yang dibatasi oleh waktu, baik itu hanya sebentar maupun lama masa waktunya. Seperti seorang laki-laki yang berkata kepada seorang wanita, "Aku menikahimu selama beberapa jam atau satu bulan." Ataupun perkataan yang memiliki makna sama 
dengan perkataan tersebut, yang di dalamnya tidak terkandung makna pernikahan secara mutlak dan mengikat untuk selamanya hingga terjadi hal-hal yang menyebabkan perpisahan antara suami dan istri (Syafi'i bin Idris, 2010).

Sedangkan menurut kalangan ulama Hanabilah, nikah mut'ah memberikan syarat-syarat seorang laki-laki menikahi seorang wanita pada waktu tertentu, talak pada waktu tertentu atau berniat di dalam hatinya untuk menceraikannya pada jangka waktu tertentu. Nikah mut'ah juga merupakan suatau bentuk perkawinan seorang laki-laki asing (pendatang) dengan maksud untuk menceraikan si wanita jika meninggalkan daerah yang ditempatinya (Az-Zuhaili, 2011).

Menurut Syarafuddin Al-Musawi dari kelompok Syiah, nikah mut'ah adalah apabila seorang wanita mengawinkan dirinya dengan seorang pria dalam keadaan tidak ada hambatan apapun yang membuatnya haram untuk dinikahi, sesuai dengan yang terdapat dalam syariat. Hambatan tersebut baik berupa hambatan nasab, semenda, persusuan, ikatan perkawinan dengan orang lain, masa iddah, atau hambatan lainnya yang sesuai dengan aturan agama Islam. Apabila wanita tersebut terbebas dari hambatan-hambatan tersebut di atas maka ia dapat menikahkan dirinya kepada seorang pria dengan mahar dalam jumlah tertentu dan dengan jangka waktu tertentu yang telah disepakati oleh kedua belah pihak, baik itu tiga hari, seminggu, sebulan, ataupun lebih dari itu (al-Musawi, 2002).

Sedangkan Ja'far Murtadha Al-Amili mendefinisikan nikah mut'ah sebagai ikatan perkawinan antara seorang pria dan seorang wanita, dengan mahar yang disepakati yang disebutkan dalam akad dengan batas waktu yang telah ditentukan. Dengan berlalunya waktu yang telah disepakati, atau dengan pengurangan batas waktu yang diberikan oleh pihak laki-laki, maka ikatan perkawinan terputus tanpa memerlukan proses perceraian (Ja'far Murtadha Al-Amili, 1992).

Sama seperti pernikahan permanen dalam Islam, pada nikah mut'ah juga tentu terdapat rukun dan syaratnya (Murata, 2001) yang harus dipenuhi agar pernikahan yang dilakukan sah, di antara rukun dan syarat tersebut ialah 1) ijâb-qabûl, 2) kedua calon mempelai, 3 ) periode waktu (muddah), dan 4) mahar.

Ijab dan qabul dalam nikah mut'ah berbeda dengan pernikahan permanen. Dalam nikah mut'ah, lafadz ijab dari pihak wanita dengan mengucapkan "Engkau ku mut'ahkan...atas diriku dengan mas kawin...selama...hari, bulan atau tahun". Dalam pengucapan durasi tenggang waktu perkawinan harus ditentukan dengan jelas. Kemudian dijawab oleh pihak laki-laki dengan mengucapkan "Aku terima" tanpa ditambah ucapan yang lain (al-Musawi, 2002). Adapun wali dalam nikah mut'ah tidak diperlukan untuk wanita dewasa. Sehinga wanita dewasa dapat menikahkan dirinya sendiri (Amir, 2014).

Ketentuan dua calon mempelai sama halnya dengan syarat dalam perkawinan permanen. Kemudian mengenai periode waktu (Muddah) harus ditetapkan dengan jelas sampai kapan durasi perkawinan akan berlangsung sehingga tidak ada penambahan atau pengurangan waktu setelah akad dilaksanakan. Adapun mahar dalam nikah mut'ah menjadi rukun sahnya sebuah pernikahan, ini berbeda dalam pernikahan permanen. Menurut Scahiko Murata sebagaimana dikutip dari Imam Ja'far yang menyampaikan sebuah hadis "Tidak ada nikah mut'ah kecuali dua hal, jangka waktu yang ditetapkan dan mahar tertentu." (Murata, 2001) Dalam akad nikah mut'ah ini diharuskan menyebutkan mahar dari harta yang dapat diiketahui dengan cara melihatnya langsung, namun untuk mahar yang tidak dapat dihadirkan cukup dideskripsikan sedemikian rupa hingga pihak wanita mengetahui dengan jelas. Mengenai jumlah besaran mahar dikembalikan pada kesepakatan antara kedua belah pihak.

\section{Legitimasi Nikah Mut'ah}

Penganut mazhab Syiah tentunya punya dasar legitimasi kebolehan dilakukannya 
nikah mut'ah, baik bersumber dari Alquran maupun hadis Nabi. Dalil Alquran yang sering digunakan adalah Q.S An-Nisa ayat 24. Menurut Muhammad Husain alTabatabi dalam Al-Mizan Fi Tafsir Alquran mengatakan bahawa kata "istimtâ" pada surat An-Nisa ayat 24 tersebut menunjukkan adanya nikah mut'ah dan dipraktekkan para sahabat Nabi (Muhammad Husain AtTabatabai, 1972).

Ada beberapa hadis yang menerangkan tentang nikah mut'ah, seperti hadis dari kitab Shahih Muslim nomor 1404, 1406 dan 1407 (Al-Hajjaj, n.d.), Shahih Bukhari hadis nomor 5115 (Abi Abdillah Muhammad bin Ismail bin Ibrahim bin Al-mughirah Bardizbah Al-Bukhari, n.d.), dan Sunan Ibnu Majah hadis nomor 1963 (Al-Qazwini, n.d.).

Hadis-hadis di atas jika dicermati menunjukan bahwa Rasululah SAW pernah melegalkan praktek nikah mut'ah. Adapun pelarangan nikah mut'ah terdapat tiga pendapat; 1) larangan saat pemerintahan Umar bin Khattab, 2) larangan berasal dari Rasulullah saat pembebasan Kota Makkah sebagaimana hadis yang diriwayatkan Imam Muslim dari Sabroh AL-Juhaini "Wahai umat manusia sekalian, sesungguhnya aku pernah melegalkan kalian melakukan nikah mut'ah, dan sesungguhnya Allah telah mengharamkan perbuatan tersebut hingga hari kiamat" (Al-Hajjaj, n.d.), 3) larangan dari Rasulullah saat perang khaibar sebagaimana hadis Ali bin Abi Thalib yang diriwayatkan oleh Imam Muslim dan Ibnu Majah yang menyatakan bahwa Rasulullah melarang nikah mut'ah dan memakan daging keledai peliharaan pada saat perang khaibar (AlQazwini, n.d.) (Al-Hajjaj, n.d.).

\section{Pandangan Ulama tentang Nikah Mut'ah}

Nikah mut'ah merupakan salah satu tema dalam hukum keluarga Islam yang selalu menjadi kontroversi dari dulu hingga kini di kalangan para ahli fikih atau ulama' mengenai status hukumnya terutama di kalangan para ahli fikih Sunni dan Syiah. Di sini akan dipaparkan sekilas pandangan para ahli fikih atau ulama, baik dari kalangan Sunni maupun Syiah.

Menurut ulama Syafi'iyah jika seorang laki-laki menikah dengan syarat adanya khiyâr (pilihan) maka akadnya tidak sah. Karena akad tersebut dapat dibatalkan oleh adanya kesepakatan waktu. Sebab itu, pernikahan menjadi batal dengan adanya kesepakatan khiyâr seperti hal dalam jual beli (Az-Zuhaili, 2011). Sedagkan menurut para ulama Hanafiyah nikah mut'ah merupakan salah satu akad nikah yang rusak dan tidak sah. Pernikahan yang rusak tidak mempunyai status hukum sebelum terjadi hubungan intim. Demikian juga tidak ada sedikitpun konsekuensi pernikahan yang berlaku di dalamnya. Namun jika terjadi hubungan suami-istri maka itu merupakan kemaksiatan dan keduanya wajib dipisahkan. Meskipun merupakan pernikahan yang rusak, tetapi pelakunya tidak bisa dikenakan hukuman had untuk perbuatan zina. Melainkan hanya dikenakan hukuman ta'zir yang dapat dianggap sebagai peringatan (Az-Zuhaili, 2011).

Para ulama Malikiyah juga memandang bahwa nikah mut'ah merupakan pernikahan yang tidak sah dan rusak dalam salah satu rukun atau syarat sahnya nikah (Az-Zuhaili, 2011). Ulama' Sanâbilah juga mengatakan nikah mut'ah termasuk dalam kategori pernikahan yang tidak sah dari asalnya. Hal ini dikarenakan dalam akadnya nikah mut'ah terdapat pembatasan waktu. Ulama Hanâbilah menyatakan apabila seorang lakilaki menikahi seorang wanita untuk jangka waktu tertentu, memberikan syarat untuk menceraikannya pada waktu tertentu atau berniat di dalam hatinya untuk menceraikan dalam jangka waktu tertentu, maka seseorang yang telah melaksanakan akad seperti ini akan dikenakan ta'zir dan nasab anak disandarkan pada ibunya (Az-Zuhaili, 2011). Dari pemaparan-pemaran tersebut dapat disimpulkan bahwa menurut jumhur ulama dari empat mazhab sepakat nikah mut'ah adalah nikah yang tidah sah dan rusak.

Berbeda dengan para ulama Sunni, ulama Syiah mempunyai pandangan yang berbeda tentang nikah mut'ah. Ja'far Murtada Al-Amili, berpendapat bahwa nikah mut'ah adalah halal untuk dilakukan dan berlaku selamanya hingga hari kiamat. 
Al-Amili menganggap bahwa baik ayat maupun hadîs yang berkaitan dengan penghapusan nikah mut'ah tidak dapat dijadikan hujjah ataupun dalil, hal ini dikarenakan hadîs- hadîs tersebut hanya diriwayatkan oleh perorangan saja atau yang dikenal dalam ilmu hadîs sebagai hadîs ahad, baik dari kalangan sahabat maupun tabi'in. Beliau juga mengatakan riwayatriwayat yang mengharamkan nikah mut'ah itu bertentangan dengan riwayat-riwayat yang menghalalkan nikah mut'ah di mana pada riwayat-riwayat yang menghalalkan nikah mut'ah jumlah perawinya lebih banyak dan lebih kuat. Al-Amili menganggap bahwa baik ayat maupun hadîs yang berkaitan dengan penghapusan juga membantah ungkapan-ungkapan ulama' Sunni yang mengatakan bahwa nikah mut'ah dinasakh oleh surat AlMu'minûn. Karena menurutnya ayat-ayat yang menerangkan tentang menjaga kemaluan itu turun lebih dulu dibanding dengan ayat yang menjelaskan nikah mut'ah, dan bagaimana mungkin ayat yang turun lebih dulu dapat menasakh ayat yang turun setelahnya (Ja' far Murtadha Al-Amili, 1992).

Menurut Abd Al-Husain Syarafuddin Al-Musawî, nikah mut'ah hukumnya halal dan sah dalam pelaksanaannya. Al-Musawî berpendapat ayat Alquran yang menjelaskan tentang nikah mut'ah merupakan ayat qam'i dan dapat diamalkan. Selain itu Al-Musawî juga menyatakan bahwa tidak ada penghapusan hukum nikah mut'ah pada surat An-Nisa' oleh ayat nikah, talaq, dan iddah. AlMusawî mempertanyakan bagaimana mungkin ayat yang turun di Makkah dapat menasakh ayat yang turun di Madinah. Sedangkan apabila dikatakan bahwa nikah mut'ah dinasakh oleh hadîs-hadîs yang mengharamkannya, menurutnya ini juga tidak benar, karena ketetapan hukum yang lebih tinggi tidak mungkin dapat dibatalkan dengan ketetapan hukum yang lebih rendah darinya. Al-Musawi juga menganggap bahwa hadîs-hadîs yang menghapus atau membatalkan nikah mut'ah merupakan hadîs palsu, karena disusun oleh beberapa kalangan yang hidup sesudah zaman para Khalifah yang empat, meskipun hadîs-hadîs tersebut diriwayatkan oleh Al-Bukhari dan Muslim. Dalam hal ini Al-Musawi hanya mengakui hadîs-hadîs mutawatir yang berasal dari para Ahlul Bait Nabi SAW yang merupakan para imam Syiah yang ma'sûm (al-Musawi, 2002).

Menurut Sayid Husain Nashr dan Muhammad Husain, nikah mut'ah hukumnya halal dan sah untuk dipraktekkan. Menurut mereka nikah sudah dilakukan sejak zaman Nabi Muhammad saw. hingga kematian beliau. Bahkan setelah kematian Nabi Muhammad saw. nikah mut'ah masih dilakukan pada zaman Khalifah Abu Bakar ra. hingga pada sebagian masa pemerintahan Umar ra. Kaum muslimin pada masa itu masih melakukan nikah mut'ah sampai Khalifah Umar benar-benar melarangnya. Sama seperti pandangan kedua tokoh sebelumnya mereka juga menolak adanya penghapusan atau naskh surat An-Nisa' ayat 24 yang menurut mereka ayat ini menjelaskan tentang nikah mut'ah, baik dengan ayat lain seperti surat Al-Mu'minûn ayat 5-7 maupun oleh hadîs-hadîs yang menjelaskan tentang pelarangan nikah mut'ah (Muhammad Husain T, 2013).

\section{Sekilas Syiah di Yogyakarta}

Sejarah mencatat masukannya Syiah di Indonesia bersamaan dengan awal agama Islam disebarkan di Indonesia melalui pedagang-pedagang Persia yang tinggal di Gujarat (Hamdi, 2012). Menurut Azyumardi Azra sebagaimana dikutip dari Yunus Jamil, bahwa Syiah pertama di Indonesia berada di Aceh dengan didirikannya kerajaan Perlak pada tahun $854 \mathrm{M}$ oleh para pedagang muslim asal Persia, Gujarat dan Arab. Mereka mengangkat Sayyid Maulana Abdul Aziz Syah sebagai sultan pertama Kerajaan Perlak yang merupakan seorang keturunan Arab-Qurays dan penganut Syiah (Azra, 1995). Pada masa ini Syiah menjadi politik yang tanggung di Nusantara (Hasim, 2012) sebelum pada masa kepemimpinan 'Ala Ad-din Maulana Mughayat Syah yang mengalami 
pemberontakan dan penggulingan kekuasaan oleh kelompok Sunni (Azra, 1995).

Terdapat beberapa bukti lain bahwa Syiah pernah memasuki Indonesia dengan ritual keagamaannya yang mempengaruhi tradisi umat Islam di Indonesia, seperti ritual tabut Hasan-Husain di Bengkulu, Hoyak Hosen di Pariaman, Sumatera Barat, tradisi kenduri di lingkungan masyarakat Islam Nusantara (Humaini, 2019) dan ritual Asyuro yang dilakukan setiap 10 Muharram (Aceh, 1985).

Berbicara asal-usul munculnya Syiah di Yogyakarta juga tidak lepas dari sejarah runtuhnya Kerajaan Majapahit yang melahirkan kerajaan-kerajaan baru di tanah Jawa yang bercorak Islam. Kerajaan tersebut di antaranya adalah Kerajaan Islam Demak, Kerajaan Pajang, dan Kerajaan Mataram Islam. Islam masuk ke wilayah Mataram pada masa Pemerintahan Hadiwijaya (Joko Tingkir) dan Ki Ageng Pamenahan, mereka berdua merupakan murid dari Sunan Kalijaga, sehingga pemahaman yang dianut masyarakat Mataram secara umum pada saat itu ialah Sunni (Widji, 1995). Namun tidak dapat dilupakan dari sejarah, paham Syiah juga menyebar di bumi Mataram bersamaan Syekh Siti Jenar yang merupakan salah seorang da'i syiah (Abdullah, 2015) memiliki pengaruh besar di wilayah Jawa, khususnya di Panggung dan Pengging. Meskipun ajaran Syiah tidak terlalu banyak pengikutnya sebagaimana ajaran Sunni. Menurut Jalaluddin Rahkmat, tidak berkembangnya Syiah di masa Kerajaan Mataram karena orang-orang syiah pada masa itu banyak yang melakukan taqiyah dan mereka tidak memiliki semangat misionaris untuk menyebarkan syiah (Rahmat, 2000).

Kompleksitas perubahan masyarakat telah menyemai kehidupan Syiah di Indonesia. Setelah keberhasilan Revolusi Iran, aktivisme Syiah di Indonesia mulai kelihatan. Orang-orang Syiah mulai berani menampilkan identitas keagamaan mereka. Di beberapa tempat orang-orang Syiah giat berdakwah Islam kendatipun masyarakatnya menganut paham Sunni.
Yayasan-yayasan Syiah telah dibentuk di beberapa kota, antara lain Jakarta, Bogor, Depok, Bandung, Pekalongan, dan Bangil. Yayasan tersebut ternaung dalam Ikatan Jama'ah Ahlul Bait Indonesia (IJABI). Kegiatannya meliputi jamaah pengajian, penerbitan, dan distribusi buku dan pendidikan atau pondok pesantren (Pierewan, 2007).

Di Yogyakarta, cikal bakal berdirinya IJABI dimulai dengan adanya kelompokkelompok diskusi mahasiswa yang mengkaji masalah kemasyarakatan. Kelompok-kelompok tersebut kemudian menamakan dirinya dengan Rausyan Fikr. Rausyan Fikr merupakan kelompok kajian -kebanyakan diikuti oleh mahasiswa- yang banyak sekali mengkaji pemikiran Ahlul Bait terutama dari beberapa pemikir antara lain Ali Syari'ati, Murtadha Muthahhari, dan Jalaluddin Rakhmat. Nama Rausyan Fikr sendiri berasal dari konsep Ali Syari'ati yang berarti orang-orang atau inetelektual yang tercerahkan (Pierewan, 2007).

Dalam awal pembentukannya lembaga ini belum mempunyai akte pendirian dan landasan hukum, baru pada tanggal 14 Februari 1995 lembaga ini berubah menjadi Yayasan Rausan Fikr dan memiliki landasan hukum dengan ketua Romy Fibri. Yayasan ini merupakan satu-satunya yayasan yang berafiliasi dengan Syiah di Yogyakarta (Ansori, 2005).

\section{Pandangan Tokoh Syiah Yogyakarta tentang Nikah Mut'ah}

Dari hasil wawancara dengan para tokoh Syiah Yogyakarta, mereka memiliki pandangan yang sama berkaitan dengan kebolehan melakukan nikah mut'ah dari sudut pandang fikih mazhab Syiah. Namun mengenai prakteknya di Indonesia, mereka memberikan penjelasan yang berbeda-beda.

Narasumber pertama adalah WSA (nama disamarkan). WSA menjelaskan bahwa nikah mut'ah tidak seperti kebanyakan orang pikirkan. Nikah mut'ah lebih ditekankan pada kepatuhan dari syarat-syarat atau isi kesepakatan yang telah disepakati oleh kedua belah pihak. Sedangkan yang mengajukan syarat 
sebelum dilakukan nikah mut'ah adalah pihak wanita, jika sudah janda atau telah dewasa, jika dia masih gadis maka harus didampingi oleh walinya. Syarat tersebut bisa dalam bentuk jumlah mahar, ataupun apa saja yang boleh diperbuat oleh suami terhadapnya dan apa saja yang tidak boleh. Contohnya sebelum akad nikah pihak wanita memberikan syarat kepada calon suami bahwa ia hanya sebatas mahram untuk menemani ketika istri hendak berpergian tanpa ada hubungan suami istri selama pernikahan dan sampai batas waktu nikah tersebut habis. Hal ini dilakukan dengan tujuan untuk memuliakan wanita, karena jika kedua selama melakukan nikah mut'ah merasa cocok satu sama lain, maka pernikahan mut'ah tersebut bisa diteruskan menjadi nikah $d a^{\prime} i m$ setelah masa mut'ahnya selesai.

Sedangkan untuk praktek nikah mut'ah di Indonesia khususnya di Yogyakarta, WSA mengatakan "Disini mayoritas masyarakatnya kan berpaham Sunni, prakteknya ya harus berhati-hati bener mas, tidak sembarangan bisa dilakukan, ketika terpaksa melakukan, ya harus benar-benar dengan sesama pengikut Syiah. Hal itu untuk upaya preventif terjadinya gesekan di masyarakat yang secara umum berpaham Sunni."

Selanjutnya wawancara dengan HK. Penjelasan yang diberikan HK hampir sama dengan apa yang dijelaskan oleh WSA. Dalam nikah mut'ah yang terpenting adalah kesepakatan oleh kedua belah pihak. Pada nikah mut'ah kesepakatan yang ditekankan dan bukan atas dasar nafsu, maka nikah mut'ah bisa menjadi solusi agar terhindar dari perzinahan karena belum mampu melakukan nikah permanen. Dalam nikah mut'ah tersebut pihak wanita memberikan syarat kepada pihak laki-laki bahwa selama nikah mut'ah pihak laki-laki dilarang menggauli dirinya sampai habis masa waktunya. Kemudian bisa dilanjutkan dengan nikah permanen jika sudah mampu. Adapun prakteknya, HK mengatakan "boleh-boleh saja mas, asal kesepakatan kedua belah pihak sudah disetujui". Menurut HK nikah mut'ah merupakan sumpah di hadapan Allah swt., Rasulullah saw., dan para Imam yang tidak boleh dilanggar.

Narasumber berikutnya adalah AD. AD menjelaskan bahwa nikah mut'ah secara fikih Ja'fari hukumnya adalah mubâh dan legal secara prakteknya di Iran. Berbeda jika membahas nikah mut'ah di Indonesia khususnya Yogyakarta. "Ya secara fikihnya boleh-boleh aja, tapi prateknya ya ndak boleh". Larangan tersebut kata AD disebabkan adanya perbedaan paham yang dianut oleh mayoritas penduduk Indonesia dengan mayoritas penduduk Iran dan juga untuk menghindari terjadinya konflik di tengah masyarakat di kemudian hari. Selain itu dalam peraturan yang ada di Indonesia melakukan nikah permanen yang tidak dicatatkan (sirri) adalah hal yang dilarang terlebih lagi pernikahan yang sifatnya sementara dan dibatasi dengan waktu tertentu.

\section{Pandangan Tokoh Syiah Yogyakarta tentang Nikah Mut'ah Perspektif Hukum Islam dan Implementasinya di Era Kontemporer}

Gagasan perubahan suatu hukum dalam hukum Islam merupakan hal yang tidak dapat dihindari. Selama 14 abad lebih sejak kehadiran Islam di muka bumi, hukum Islam telah terbukti mampu menjadi sumber hukum utama dunia Islam yang telah memasuki berbagai macam situasi zaman. Hukum Islam bertemu dengan berbagai bangsa dan berbagai macam kebudayaan. Hal ini dikarenakan hukum Islam memiliki keluwesan dan tidak bersifat kaku dalam penerapannya. Hukum Islam dapat berubah sesuai kondisi waktu, tempat, dan keadaan tertentu. Keluwesan ini dimaksudkan untuk mengatasi semua kesulitan dan permasalahan yang muncul (Al-Qardhawi, 1993). Salah satu bukti keluwesan hukum Islam dapat dilihat dari adanya suatu kaidah fikih yang berbunyi "Tagaiyyur al-Ahkâm bi tagaiyyir al-Azmanah wa al-Amkanah wa alAhwâl" (hukum dapat berubah tergantung dengan waktu, tempat dan keadaan).

Kaidah di atas menjelaskan bahwa bahwa terdapat tiga faktor yang menyebabkan terjadinya perubahan suatu hukum dalam Islam, yaitu waktu, tempat, 
dan keadaan. Kaidah tersebut menegaskan suatu keadaan tertentu yang dialami individu maupun masyarakat dapat mempengaruhi perubahan hukum bagi individu maupun masyarakat itu sendiri. Dari perluasan kaidah di atas akan digunakan untuk menganalisa pandangan para tokoh Syiah Yogyakarta.

Dari wawacara yang dilakukan dengan tiga tokoh Syiah Yogyakarta terhadap pandangan mereka tentang nikah mut'ah, ditemukan pendapat yang berbeda-beda. Pendapat pertama berasal dari AD. AD melarang adanya praktek nikah mut'ah di Yogyakarta dengan alasan perbedaan daerah dan kondisi penganut Syiah di Indonesia dan Iran. Kondisi penganut Syiah di Yogyakarta adalah minoritas. Larangan ini tentu lebih mendatangkan kemaslahatan baik untuk penganut Syiah maupun Sunni yang ada di Yogyakarta agar terhindar dari konflik di antara pengikut Sunni dan Syiah. Hal ini selaras dengan kaidah Fikih: Dar almafâsid muqaddam 'ala jalb al-masâlih (menghindari terjadinya kerusakan wajib lebih didahulukan daripada upaya mencapai maslahat) (Djazuli, 2006).

Selanjutnya pandangan WSA mengenai praktek nikah mut'ah di Yogyakarta. Dalam prakteknya ia mengijinkan nikah mut'ah, namun menyarankan lebih berhati-hati dalam melakukan nikah mut'ah. Kehatihatian itu dengan melakukan nikah mut'ah dengan sesama penganut Syiah. Karena jika tidak benar-benar dengan sesama penganut Syiah, dikhawatirkan akan terjadi permasalahan di tengah masyarakat yang mayoritas penganut Sunni. WSA secara tidak langsung mengatakan bahwa nikah mut'ah diperbolehkan hanya dalam keadaan darurat, yakni terbatas hanya dengan sesama penganut Syiah.

Selanjutnya pandangan dari HK mengenai penerapan nikah mut'ah di Yogyakarta. Beliau menjelaskan bahwa nikah mut'ah dalam fikih Ja'fariyah hukumnya adalah boleh (mubâh), maka begitupula dengan prakteknya, baik itu di Iran sana yang masyarakatnya mayoritas merupakan penganut Syiah, maupun di Indonesia yang masyarakatnya mayoritas merupakan penganut Sunni, hal itu tidak mempengaruhi kebolehan mempraktekkan nikah mut'ah. Selain itu juga nikah mut'ah merupakan hak individu penganut Syiah, mereka bebas untuk melakukannya ataupun tidak.

Menurut HK, pernikahan mut'ah juga dapat menjadi alternatif untuk menghindarkan perbuatan zina. Misalnya dalam perbuatan pacaran yang banyak berujung kepada perbuatan dosa bahkan perzinaan. Menurut HK, budaya pacaran yang sering kali berlandaskan nafsu dan penipuan, maka akan lebih jelas bila pacaran itu dibingkai dalam suatu perjanjian kontraktual (nikah mut'ah). Dalam perjanjian itu, boleh-boleh saja dicantumkan beberapa kesepakatan, termasuk syarat tidak adanya hubungan badan. Bahkan mungkin prasyarat lain yang ingin disepakati dalam kontrak tersebut oleh kedua belah pihak. Sehingga tidak ada yang dirugikan dalam hal ini. Hal ini selaras dengan kaidah: Idza ta'arda mafsadatâni ru'iya a'dhamuhâ dararan bi irtikâbi akhaffihimâ (Apabila ada dua mafsadat bertentangan, maka yang harus ditinggalkan adalah mafsadat yang mudaratnya lebih besar, dengan melakukan mudarat yang lebih ringan) (Djazuli, 2006).

Perbedaan tokoh-tokoh Syiah Rausan Fikr tidak terlepas dari ketegangan historis maupun kajian fikih. Permasalahan nikah mut'ah memang masalah perdebatan panjang dari dahulu. Perdebatan ini, menyisahkan dua kelompok besar jumhur (mayoritas ulama) dan Syiah. Dua aliran tersebut telah menunjukkan pendirian masing-masing dalam menetapkan hukum nikah mut'ah, antara mengharamkan dan menghalalkan. Al-Kulainy sebagai tokoh Syiah menyatakan bahwa nikah mut'ah disyariatkan melalui Alquran dan tak satu ayat pun yang menasakhnya serta diberlakukan oleh Sunnah Nabi untuk waktu yang terbatas (Abu Ja'far Muhammad bin Ya'qub al-Kulainiy, 1985, $\mathrm{h}$. 449). Argumentasi tersebut merujuk kepada Alquran Q.S Al-Nisa [4]: 24 "Dan dihalalkan bagi kamu selain yang demikian, (yaitu) mencari istri-istri dengan hartamu untuk dikawini bukan 
untuk berzina. Maka istri-istri yang telah kamu nikmati (campuri) di antara mereka, berikanlah kepada mereka maharnya (dengan sempurna)."

Menurut pemahaman Syiah, lafad Istamta'tum yang tercantum pada ayat tersebut mengandung makna nikah mut'ah. Yakni perkawinan yang dilaksanakan secara terputus, lazimnya disebut 'aqd al-intiqa' (perkawinan yang terbatas dengan waktu tertentu) (Muhammad Husain Ali Kasyif alGita, n.d., h. 101-102). Argumentasi tersebut dikuatkan beberapa pendapat mufassir di antaranya 1) Abd Razak dari Ata', ia berkata bahwa ayat 24 dalam surat al-Nisa menjelasakan keberadaan batas waktu dalam nikah, ialah nikah mut'ah (Abd alRahman Jalal Al-Din Al-Suyuti, 1983, h. 484), 2) Muhammad bin Husain dari Al-Sadiy, ia berkata bahwa ayat 24 surat al-Nisa adalah ayat mut'ah, yakni seorang laki-laki mengawini seorang wanita dengan syarat dan waktu tertentu (Abu Ja' far Muhammad bin Jarir al-Tabariy, 1954, h. 12), 3) alTabatabai, mufassir Syiah, menjelaskan bahwa ayat itu menunjukan nikah mut'ah dilihat dari lafaz sebelumnya "...mencari wanita dengan hartamu untuk memelihara kesucian bukan untuk berzina.."(Muhammad Husain At-Tabatabai, 1972).

Sedangkan kelompok Sunni yang mengharamkan mut'ah beragumentasi dengan Q.S. al-Mukminun [23]: 5-7 "Dan orang-orang yang menjaga kemaluannya. Kecuali terhadap istri-istri mereka atau budak yang mereka miliki. Maka sesungguhnya mereka dalam hal ini tiada tercela. Barangsiapa mencari yang di balik itu, maka mereka itulah orangorang yang melampaui batas." Ayat tersebut adalah membatasi hubungan kelamin yang dihalalkan, yaitu hanya terhadap wanita yang berfungsi istri atau budak yang dimiliki. Di luar ini (mâ warâa aýâlika) sebagai nikah mut'ah tidak boleh, karena tidak berfungsi sebagai istri.

Selain berdasarkan ayat Alquran argumentasi Sunni juga dikuatkan dengan hadis Nabi "Telah bersabda Rasulullah saw. Sungguh aku telah bolehkan kepada mu nikah mut'ah dengan para wanita, dan sungguh Allah telah mengharamkan yang demikian itu sampai hari kiamat, maka barangsiapa yang ada punya wanita, maka hendaklah ikuti jalan-Nya, dan jangan mengambil dari mahar yang telah kamu berikan padanya." (Ibn Hajar al-Asqalani, n.d., h. 208). Pada mulanya Nabi saw. pernah memperkenankan nikah mut'ah, lalu ia mengharamkannya. Jadi, pembolehan mut'ah otomatis mansukh (telah dilarang/ diharamkan).

Dilihat dari perspektif Alquran dan hadis (sebagaimana yang telah dikemukakan di atas), menurut mazhab Sunni dapat disimpulkan bahwa nikah mut'ah memang telah diharamkan oleh Rasulullah. Sebab-sebab pengharamannya telah banyak diulas oleh para ulama, di antaranya adalah karena nikah mut'ah semata-mata sebagai tempat untuk melampiaskan nafsu syahwat, sehingga tidak jauh berbeda dengan zina (komunisme seksual).

Terlepas adanya perbedaan pendapat dua aliran tersebut, sebenarnya dapat dikompromikan menjadi; 1) diharamkan di luar situasi peperangan, dan 2) dibolehkan dalam keadaan peperangan. Jadi, nikah mut'ah harus dipahami pembolehannya dalam keadaan darurat. Pendapat ini sebagaimana pendapat Ibnu Abbas yang membolehkan nikah mut'ah dengan catatan hanya dalam kondisi darurat (Al-Syaukani, 1961). Maksudnya, nikah mut'ah tidak dapat diterima dalam keadaan normal, namun dalam keadaan darurat tentu dapat dipertimbangkan dan dilihat mana lebih besar maslahat dan mudaratnya. Bagi penulis, mut'ah hendaknya tidak dipandang sebagai bentuk pernikahan liar. Mut'ah tetap memiliki beragam persyaratan yang juga sangat ketat. Apalagi bila ditambah dengan sifatnya yang kontraktual (tidak hanya dalam hal waktu, namun juga dalam hak dan kewajiban). Oleh karena itu, jangan terlalu mudah untuk mengkafirkan seseorang hanya dia meyakini kehalalan mut'ah. Ruang diskusi tetap harus dibuka selebar-lebarnya dalam menyikapi kontroversi seputar nikah mut'ah ini.

\section{Kesimpulan}

Terdapat perbedaan pendapat di kalangan tokoh Syiah Yogyakarta tentang 
nikah mut'ah dan penerapannya. Terdapat tiga pendapat, yaitu 1) melarang secara mutlak karena alasan perbedaan tempat dan kondisi antara Indonesia dengan Iran, 2) membolehkan dengan syarat pernikahan harus dilakukan dengan sesama penganut Syiah, 3) membolehkan secara mutlak dengan mengacu pada fikih dari mazhab Syiah ja'fari tanpa mempertimbangkan perbedaan kondisi dan tempat.

Penerapan nikah mut'ah dalam era kekinian, penulis lebih condong kepada pendapat Ibnu Abbas yang membolehkan nikah mut'ah dengan catatan tidak dapat diterima dalam keadaan normal, namun dalam keadaan darurat tentu dapat dipertimbangkan dan dilihat mana lebih besar maslahat dan mudaratnya. Selain itu bagi penulis, mut'ah hendaknya tidak dipandang sebagai bentuk pernikahan liar. Nikah mut'ah tetap memiliki beragam persyaratan yang juga sangat ketat. Apalagi bila ditambah dengan sifatnya yang kontraktual (tidak hanya dalam hal waktu, namun juga dalam hak dan kewajiban). Oleh karena itu, jangan terlalu mudah untuk mengkafirkan seseorang hanya dia meyakini kehalalan mut'ah. Ruang diskusi tetap harus dibuka selebar-lebarnya dalam menyikapi kontroversi seputar nikah mut’ah ini.

\section{Ucapan Terima Kasih}

Peneliti mengucapkan terimaksih kepada Jurnal Dialog Badan Litbang dan Diklat Kementerian Agama RI telah memberikan kesempatan peneliti untuk andil mengirimkan naskah hasil penelitian ini. Terimaksih juga peneliti ucapkan kepada Yayasan Rausan Fikr dan para tokoh narasumber AD, SWA dan HK, yang namanya peneliti samarkan atas permintaan narasumber, sehingga peneliti memperoleh informasi, pengalaman, wawasan dan pengetahuan yang cukup terkait nikah mut'ah di era sekarang menurut penganut paham Syiah di Indonesia (Yogyakarta).[]

\section{Daftar Pustaka}

'Abdirrazzaq, A. H. U. bin K. bin. (2010). Panduan Lengkap Nikah dari " $A$ " sampai
“Z." Jakarta: Pustaka Ibnu Katsir.

Abd al-Rahman Jalal Al-Din Al-Suyuti. (1983). Al-Dur Al-Masur fi Tafsir Al$M a^{\prime}$ tsur (Jilid II). Beirut: Dar al-Fikr.

Abdullah, R. (2015). Sultan Fattah: raja Islam pertama penakluk Tanah Jawa, 1482-1518 M. Solo: Al-Wafi Publishing.

Abi Abdillah Muhammad bin Ismail bin Ibrahim bin Al-mughirah Bardizbah Al-Bukhari. (n.d.). Shahih Bukhari (Jilid 3). Beirut: Dar al-Kutub al-'Ilmiyah.

Abu Ja'far Muhammad bin Jarir al-Tabariy. (1954). Jami' al-Bayan an-Ta'wil Alquran (Juz 4). Mesir: Syirkah Maktabah wa Matba'ah Mustafa al-Babiy al-Halabiy wa Awladuhu.

Abu Ja'far Muhammad bin Ya'qub alKulainiy. (1985). Furu' Al-Kafiy (Juz V). Beirut: Dar al-Adwa.

Aceh, A. (1985). Sekitar Masuknya Islam ke Indonesia (Cet 4). Solo: CV. Rahamadhani.

Agus. (2008). Interaksi Sosial Masyarakat Syi'ah-Sunni Di Tengah Pluralitas Keberagaman (Studi Kasus Terhadap Interaksi Sosial Syi'ah-Sunni Di Kabupaten Sleman). UIN Sunan Kalijaga.

Al-Hajjaj, A. al-H. M. bin. (n.d.). Shahih Muslim (Jilid 2). Beirut: Dar al-Kutub al-'Ilmiyah.

al-Musawi, S. (2002). Isu-Isu Penting Ikhtilaf Sunnah Shi'ah Terj. Dalam Mukhlis BA dari judul asli Al-Fushul al-Muhimmah fi Ta'if al-Ummah. Bandung: Mizan.

Al-Musayyar, S. A. (2008). Fiqh Cinta Kasih. Dalam Rahasia Kebahagiaan Rumah Tangga. Jakarta: Erlangga.

Al-Qardhawi, Y. (1993). Keluasan dan keluwesan Hukum Islam terj. Said Agil Husin al-Munawwar. Semarang: Dina Utama.

Al-Qazwini, A.-M. A. A. M. (n.d.). Sunan Ibnu Majah (Jilid 2; Muhammad Hasan Nasar, Ed.). Beirut: Dar al-Kutub al'Ilmiyah. 
Al-Syaukani. (1961). al-Nail al-Autar (Ce. 3). Mesir: Al-Halabi.

Ali, M. (2016). Hukum Nikah Mut'ah dan Hubungannya dengan Pembentukan Keluarga Sakinah (Studi Keluarga Sakinah Model Kementerian Agama). Risalah, Jurnal Pendidikan Dan Studi Islam, 3(1), 30-41. https://doi.org/ https://d oi.org/10.31943/ jurnal_risalah.v3i1.23

Amir, S. (2014). Hukum Perkawinan Islam di Indonesia (Cet V). Jakarta: Kencana.

Ansori. (2005). Syiah di Kabupaten Sleman. UIN Sunan Kalijaga.

Arifin, A. (2016). Menikah Untuk Bahagia (Edisi Terbaru). Jakarta: Elex Media Komputindo.

Atjeh, A. (1977). Aliran Syi'ah di Nusantara. Jakarta: Islamic Research Institute.

Az-Zuhaili, W. (2011). Fikih Islam wa adillatuhu, terj. Dalam Abdul Hayyie al-Kattani, dkk. (Vol. 9). Jakarta: Gema Insani.

Azra, A. (1995). Syiah di Indonesia: Antara Mitos dan Realitas. Ulumul Qur'an: Jurnal Ilmu Dan Kebudayaan, 6(4), 4-19.

Djazuli, A. (2006). Kaidah-Kaidah Fikih: Kaidah-Kaidah Hukum Islam dalam Masalah-Masalah yang Praktis. Jakarta: Kencana.

Emilia Renita AZ. (2013). 40 Masalah Syiah. Dalam J. Rakhmat (Ed.), Arbaun Syubhat Hawla Al-Syiah. IJABI.

Hamdi, A. Z. (2012). Klaim Religious Authority Dalam Konflik Sunni-Syi'i Sampang Madura. Islamica: Jurnal Studi Keislaman, 6(2), 215-231. https:// doi.org/https://doi.org/10.15642/ islamica.2012.6.2.215-231

Hasim, M. (2012). Syiah: Sejarah Timbul dan Perkembangannya di Indonesia. Harmoni, 11(4), 22-33. Retrieved from https://jurnalharmoni.kemenag.go.id/ index.php/harmoni/article/view/253

Humaini. (2019). Konflik Sunni-Syiah di Timur Tengah Persepktif Geopolitik dan Dampaknya Terhadap Hubungan Sunni-Syiah di Indonesia. Jurnal CMES, 12(2), 156-169. https://doi.org/ h t t p s://d oi .org/10.20961/ cmes.12.2.37890

Ibn Hajar al-Asqalani. (n.d.). Bulugh alMaram. Mesir: Al-Maktabah alTijariyah al-Kubra.

Idris, Lutfiah, \& Ahmadi. (2020). Wacana Nikah Mut'ah Dalam Al-Mizan Fi Tafsir Alquran Karya Al-Tabatabai. Mukammil: Jurnal Kajian Keislaman, 3(2), 172-194. Retrieved from http:// ejournal.alkhoziny.ac.id/index.php/ mukammil/article/view/106

Ja'far Murtadha Al-Amili. (1992). Nikah Mut'ah Dalam Islam, alih bahasa Abu Muhammad Jawad. Jakarta: Yayasan AsSajjad.

Jamaluddin, Y. (2020). Nikah Mut'ah Perspektif Tafsir Nuzuli Al-Jabiri. ALWAJID: JURNAL ILMU AL-QURAN DAN TAFSIR, 1(1). Retrieved from https://jurnal.iain-bone.ac.id/ index.php/alwajid/article/view/810

Maghfiroh, N., Heniyatun, H., \& Sulistyaningsih, P. (2016). Akibat Hukum Nikah Mut'ah (Kawin Kontrak) dan Pencegahannya. Kudus: LPPM STIKES Muhammadiyah Kudus.

Muhammad Husain Ali Kasyif al-Gita. (n.d.). Asl al-Syi'ah wa Ushuluha. Maktabah al-Tsaqafah al-Islamiyyah.

Muhammad Husain At-Tabatabai. (1972). Al-Mîzân Fi Tafsîr Alquran (Jilid 4). Beirut: Mu'assah Al-A'lami Lilmambû'at.

Muhammad Husain T. (2013). Mazhab Kelima: Sejarah, Ajaran, dan Perkembangannya, Alih Bahasa Ali Yahya. Jakarta: Nur Al-Huda.

Munawwir, W. (1997). Ahmad, Al-Munawwir Kamus Arab-Indonesia. Surabaya: Pustaka Progressif.

Murata, S. (2001). Lebih Jelas Tentang Mut'ah: Perdebatan Sunny dan Syiah. Jakarta: Raja Grafindo Persada. 
Noor, Z. (2014). "Isteri Sementara": Perselisihan Pendapat Ulama Mengenai Nikah Mut'ah dalam Mazhab Sunni dan Syiah. Jurnal Figh, 11, 141-174. https://doi.org/https:// doi.org/10.22452/fiqh.vol11no1.7

Pierewan, A. C. (2007). Syi'ah dan Perubahan Sosial. DIMENSIA: Jurnal Kajian Sosiologi, 1(1), 1-16. https://doi.org/ https://doi.org/10.21831/ dimensia.v1i1.3392

Profil Rausyan Fikr Institute. (n.d.). Retrieved April 17, 2019, from www.rausyanfikr.org/2013/09/profilrausyanfikr-institute.html

Rahmat, J. (2000). Dikotomi Sunni-Syi'ah Tidak Relevan Lagi. Dalam Syi 'ah dan Politik di Indonesia: Sebuah Penelitian. Bandung: Mizan.
Ruane, J. M. (2013). Dasar-Dasar Metode Penelitian: Panduan Riset Ilmu Sosial. Bandung: Penerbit Nusa Media.

Subhan. (2018). Dialektika Sunni dan Syiah Melacak Argumentasi Hukum Nikah Mut'ah. AT-TURAS: Jurnal Studi Keislaman, 5(1), 1-20. https://doi.org/ https://doi.org/10.33650/atturas.v5i1.321

Syafi'i bin Idris. (2010). Ringkasan Kitab alUmm, penerjemah Imron Rosadi Amiruddin, Imam Awaluddin. Jakarta: Pustaka Azzam.

Widji, S. (1995). Mengislamkan Tanah Jawa: Telaah atas Metode Dakwah Walisongo. Bandung: Mizan. 